\title{
MYSTICAL MIDRASH
}

\author{
Marianne Schleicher
}

\begin{abstract}
Aвstract This article conceives of mystical midrash as the act of interpreting the details of a Torah verse with the purpose of entering a meditative or ecstatic state of union with God, in which the mystic by drawing down God's insights can explain how the Torah verse mediates the micro-macrocosmic relation between God's will and the course of history. However, since mystical midrash is such a rare phenomenon in Judaism, I have chosen to highlight the various approaches to the Torah in Jewish mysticism as a background for understanding why only one of these approaches qualifies for the epithet 'mystical midrash'.
\end{abstract}

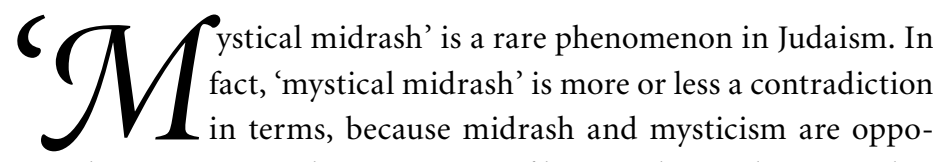
sites when it comes to the conception of how God provides counsel to his people. I shall therefore begin by explaining midrash and Jewish mysticism as two distinct phenomena. I shall furthermore explain the various approaches to the Torah in the major trends in Jewish mysticism to show why most of them cannot be characterised as midrashic. Finally and by including observations made by Moshe Idel and Elliot R. Wolfson, I shall describe the unique features of the few mystical midrashim which enable the term 'mystical midrash' after all. 


\section{Introducing the opposition between midrash and Jewish mysticism}

As an introductory illustration that is intended to advance an understanding of the opposition between midrash and Jewish mysticism I suggest Exodus 18 where a distinction is made between written counsel and mediation both reflecting the will of God.

Midrash is derived from the word derash i.e. to search for or inquire about. In Exodus 18 many Hebrew-speaking men address Moses to »inquire» (v. 15) through him about God's counsel in recognition of his direct communication with God. This communication confers upon Moses the role of a mediator who passes on God's counsel to men. However, Jethro, the experienced Midjanite priest and the caring father-in-law of Moses, warns Moses that Moses will be exhausted if he keeps on being the sole source of counsel to his people. Calling upon God (v. 19), Jethro suggests that laws should be implemented along with trustworthy representatives to execute these laws. This would leave only extraordinary matters to Moses (v. 22). God responds to Jethro's call in the following chapters of Exodus by letting Moses receive the Ten Commandments, soon expanded to the Torah, God's written counsel to his people.

It is worth noticing that Jethro in Exodus 18 distinguishes between minor matters of everyday life and major matters of extraordinary concern, cf. v. 22. From the point where the commandments are at hand, God expresses his will on everyday matters in the Torah, whereas Moses still mediates God's direct counsel in extraordinary matters. After the death of Moses, and in cases in the Hebrew Bible where the Torah does not suffice, the people of Israel still has opportunities to receive adequate counsel from God mediated by judges, kings and prophets. When prophecy ceases to be a legitimate activity among the Jews during the 2 nd century BCE, direct communication with God is still possible, though limited to the visit of the high priest in the Holiest of Holy in the Jerusalem Temple on Yom Kippur. On this extraordinary day, the high priest pleads for atonement on behalf of the entire people by addressing God directly. ${ }^{1}$ However, the legitimacy of the priestly institutions in the Temple is questioned during the Hasmonean dynasty in the 2nd and 1st century BCE, and an end comes to the existence of institutionalised mediators between God and the people 
with the destruction of the Temple in $70 \mathrm{CE}$.

This is where Jewish mysticism takes over. I venture the statement that Jewish mysticism emerges as a response to the religious need of still having mediated access to God, God's will and God's perspective in the absence of institutionalised mediators. This mediated access has as its prerequisite that someone bridges the gulf between the immanent world as we know it and the transcendent God. The rabbinic institution has never claimed the role of a mediator. It has »only» offered its expertise on how to understand the always available, written counsel from God in the corpus of canonical texts in Judaism in difficult, yet everyday matters.

\section{Traditional midrash}

To narrow the focus on the opposition between midrash and mysticism, I shall first turn to midrash. Interpretation of the Torah became one of the most important rabbinical activities after the destruction of the Temple, and 'midrash' became the term that covered this interpretative activity. As a rabbinical term, 'midrash' designates the interpretative search for God's will and written counsel in the regulating laws (midrash halakhah) and later in the biblical narratives (midrash aggadah) of the Torah. It developed from an oral form to recorded expositions made by the rabbis in order to either find the plain meaning; i.e. peshat, of a biblical verse, or to apply meaning to it; i.e. derash, to have it make sense. In the Babylonian Talmud one sentence came to influence all subsequent midrashic activity; i.e. »a verse should not lose its literal sense». ${ }^{2}$ Because of this sentence, peshat came to be considered more valuable than derash, ${ }^{3}$ and I cannot help thinking that the tendency towards literalism reflects the notion that the words of God, as written down in the Torah, were to be treasured as the primary access to God in times of exile.

In the classical period of rabbinic midrash, i.e. between the late 5 th and 8th century, complex rhetorical structures of scriptural exegesis and homily emerged. ${ }^{4}$ A typical midrash would begin with a proem, the so-called petihta, where a 'distant' verse comments on the opening verse (the seder verse) of the weekly Torah portion. The 'distant' verse and the seder verse are seemingly unrelated. However, within the 
proem, a series of exegetical bridges are constructed between the 'distant' verse and the seder verse. The two verses are joined »through their common imagery in order to make its own rhetorical point» (Stern 1987: 617). During this period, interpretation became clearly recognisable as discourse with two objectives: 1) to influence the identification of the Jews with rabbinic Judaism against rival interpretations of Judaism and 2) to »extend the Bible's laws and beliefs to the issues of their contemporary existence» (Stern 1987: 616). Midrash is here taken as a certain genre that develops into a generic mode of interpretation; i.e. as a certain type of literary activity, that addresses the Torah »as a sacred text, which can be interrogated to answer religious questions» (Idel 1993: 49) pertaining to changing historical circumstances. Thus, the text remains open to interpretation in order to meet the needs of individuals. This leads Moshe Idel, a highly respected scholar of Jewish mysticism, to claim that midrashic activity is incompatible with a too explicit or a too systematic theology, trying to control the reader. ${ }^{5}$ In fact, Idel makes this lack of a confining theology the characteristic of midrashic hermeneutics ${ }^{6}$ in opposition to e.g. mystical literatures which »were all profoundly influenced by relatively elaborated theologies, each which impinged their peculiar concerns on the canonic text» (Idel 1993: 51).

\section{Mysticism}

'Mysticism' derives from the Greek muein. Muein means either 'to close one's lips', which most likely refers to the vow of silence imposed upon the novice who was initiated into Greek mystery cults; or it means 'to close one's eyes' as one was taken underground or into a secret place only to open them in front of the revered object of the cult. ${ }^{7}$ The esoteric connotation of the word muein may still bear relevance for certain kinds of mysticism; however, modern scholars within the comparative study of religion tend to agree on only two phenomenological characteristics of mysticism: 1) The endeavour to gain access to mysteries beyond human intellectual apprehension, which generates a new understanding of the world, and 2) the experience of union with divine nature, the deity or a transcendent principle. ${ }^{8}$ The technical term for this union is unio mystica. In a monotheistic religion like 
Judaism, unio mystica includes everything from mere closeness or cleaving to God to ontological unification with God. Experiences of mystery and union both fall within the category of ASC, i.e. Altered State of Consciousness, where this-worldly language does not suffice to cover whatever is experienced, because the experience transcends what one is ordinarily conscious of in this world. Subsequently, the mystic is left with two options: 1 ) to describe his or her experience in the negative; ${ }^{9}$ i.e. to limit oneself to speak of what God is not; e.g. God is indefinable; God is infinite; or 2) to describe his or her experience by means of symbols taken from the culture that this particular mystic is set in. ${ }^{10}$ Symbolic descriptions imply that one uses this-worldly images in descriptions of God but places them in a construction or intratext in a way that reveals a semantic tension between likeness and difference. ${ }^{11}$ The tension between likeness and difference reveals that God may be like the image, but is different in so many other ways.

\section{Traditional Judaism vs. Jewish mysticism}

Turning from the general characteristics of mysticism towards the specific, Jewish mysticism is to be understood as a movement within Judaism, which means that mystical Jews adhere to the tenets of traditional Judaism. Traditional tenets include the monotheistic belief that God is the only god and that God is transcendent; i.e. beyond the apprehension of human senses. The tenets include the belief that God is the creator of the world; that God sustains creation; and that God as the zealous god continuously intervenes in history to punish or reward. Punishment and reward relate to the belief that the people of Israel has been chosen to a special covenant, committing it to keep the 613 commandments of the Torah as a way of performing the will of God. In return, God will reward each abiding individual. When all of Israel keep the commandments, God will send the Messiah to establish God's ideal kingdom with Jerusalem as its centre and with the people of Israel as its divinely sanctioned authority.

The difference between traditional Judaism and Jewish mysticism pertains to the gulf between the transcendent god and immanent creation. Jewish mystics do not consider this gulf absolute. Much in line with the phenomenological definition of mysticism, Jewish mystics 
strive to transcend this gulf to gain access to mysteries beyond human intellectual apprehension in order to perceive God's insights, will and counsel in situations out of the ordinary. Once the transcendent realm has been accessed, mediation between God and this world has become possible.

\section{The various approaches to the Torah in Jewish mysticism}

Scholars disagree as to the origin of Jewish mysticism. Some consider the liturgical practises of the Qumran community mystical, ${ }^{12}$ whereas others consider the beginning of Jewish mysticism to coincide with the emergence of the so-called Hekhalot Literature between the 2nd and the 6 th century CE. ${ }^{13}$ In either case, the mystical pioneers often took their vantage point in the Torah and used the text as an either meditative or ecstatic means.

This practise soon called for regulations, especially concerning the account of creation (Gen. 1-2,3) and of the chariot (Ezekiel 1). Only Jewish men above the age of 40, who were already so well versed in the Torah that they needed no guidance in order to extract God's written counsel from these accounts, were allowed to engage in mystical activity. ${ }^{14}$ What they did do, when leaving the peshat of the Torah verse behind, was probably to envision the biblical setting ${ }^{15}$ or to recite biblical passages along with certain physical activities that would provoke ASCs. ${ }^{16}$ Using Torah was important; however, understanding each word of the Torah was not essential, because the point was to achieve an auditory, visionary or physical experience of God. The image of the "chariot» (merkavah in Hebrew) taken from Ezekiel 1, conveying the possibility of ascent to God, caused this early trend within Jewish mysticism to be called 'merkavah mysticism'.

Along with merkavah mysticism, the account of »creation» (bereshit in Hebrew) inspired another trend which was subsequently referred to as the 'bereshit tradition'. Sefer Yetsirah, edited in the 6th century, brought the essence of this trend to the fore when it reflected on how God used the 22 Hebrew letters and the natural numbers to create the world. As Idel writes: »The Torah would thus be, for [the] author of Sefer Yetzirah, a rather limited, historical, and ritualistic condensation of potentialities inherent in the Hebrew alphabet» (Idel: 48). 
This meant that mystics by combining the letters in new ways could produce theologies replete with adequate counsel, reflecting God's transcendent perspective on this world here and now, different from the one already at hand in the Torah. Provoking ASCs through e.g. mechanical recitation of the Torah or producing new theologies different from those deductible from the Torah have nothing to do with midrashic activity; i.e. the search for God's will by interpreting the details of a Torah verse. Therefore, based on how these mystics in their mystical activities ignored the peshat of the Torah verses, one cannot speak of mystical midrash at this early stage of Jewish mysticism.

Kabbalah, probably the most famous kind of Jewish mysticism, emerged in Provence and Spain in the 12th and 13th century. Scholars distinguish between three Kabbalistic traditions. These are ecstaticprophetic Kabbalah, contemplative-theosophic Kabbalah, and Lurianic Kabbalah. All three of them arose as messianic reactions to the persecution of Jews in Europe.

The foremost representative of ecstatic-prophetic Kabbalah is Abraham Abulafia (ca. 1241-1291). Inspired by Sefer Yetsirah, Abulafia combined the 22 Hebrew letters to create an endless numbers of divine names. These trance-educing combinations of letters helped him reach a state of ecstasy, where the names helped him to focus on God. From his state of ecstasy, he would return to this world with prophetic visions of the future. Abulafia explained the persecution of the Jews as a messianic pang signalling the pending doom of the world. Abulafia legitimised his ecstatic practise by referring to the semi-mystical philosophy of Maimonides. ${ }^{17}$ According to Maimonides (1135-1204), only the rationalistically inclined individual would benefit from Providence guarding the individual, rewarding him with prophetic skills in this world, and securing him an intellectual union with God in the world-to-come. ${ }^{18}$ Obviously, the Torah lost its peshat, its literal sense, and reading the Torah became a matter of importing a confining rationalistic mysticism, and not about engaging in any interpretation of the Torah on its own premises. Thus, Abulafia would primarily use the Torah to confirm his Maimonidian worldview, which again would legitimise his ritualistic practice of reaching a state of ecstatic focus on God. Therefore, one cannot speak of mystical midrash in the case of Abulafia or in ecstatic-prophetic Kabbalah in general for that matter. 
Contemplative-theosophic Kabbalah, which also emerged in the 12 th and 13th century, provides the examples that prove that it is possible to talk about mystical midrash in Jewish mysticism after all. Inspired by Sefer Yetsirah, contemplative-theosophic Kabbalah took its point of departure in the ten natural numbers (sefirot in Hebrew). However, instead of being mere numbers with which God had created the world, the numbers were now seen to represent ten aspects of divine intervention into history on the part of the transcendent God. Thanks to the notion of the sefirot these divine aspects could now be accessed and contemplated upon. The ten sefirot were organised in a system with 22 paths, cf. the 22 Hebrew letters, uniting the sefirot. The three upper sefirot were considered almost transcendent, whereas the seven lower sefirot represented such intervening aspects as God's stern judgment and God's mercy, both apprehensible in this world on occasion. The lowest of these sefirot was the feminine sefirah Shekhinah, representing God's constant presence in this world. The sefirot thus laid the foundation for a mystical theology and at the same provided a mediating bridge between the transcendent God and the immanent world.

Sefer haBahir, also known as Midrash R. Nehunya ben haKanah, was the first literary work to present this theological conception of God intervening through emanations of his own transcendent being. Sefer haBahir appeared in Southern France at the end of the 12th century. Its primary concern was to explain the mystical significance of particular biblical verses as they are seen to reflect events in the sefirotic system during the work of creation and as an on-going process. The $613 \mathrm{com}$ mandments of the Torah were believed not only to regulate human behaviour in the created world. Keeping them had a positive effect in the divine realm. ${ }^{19}$ A sort of micro-macrocosmic relation exists between the upper realm as God's innermost being and the lower realm including the human sphere. Whatever happens in this world effects the upper world, and vice versa. Biblical verses and rabbinical sayings are seen as symbols alluding to this crucial micro-macrocosmic correlation, and thus, Sefer haBahir presents the notion of a sensus litteralis and a sensus spiritualis of the Torah, where both layers of meaning exist. ${ }^{20}$ Since the sensus litteralis of the Torah is not ignored but searched for by the mystic, one can indeed speak of Sefer haBahir as a mystical 
midrash despite the coherent theology being expressed in its sensus spiritualis.

Nahmanides (1194-1270), communal leader of and spokesman for Spanish Jewry, sensed the rising anti-Jewish atmosphere in Spain, where he, one man, defended Judaism against 250 Christian scholars in a theological dispute in Barcelona in 1263. The king of Aragon rewarded Nahmanides for his impressive performance. Nevertheless, Dominican friars, who had originally organised the dispute, accused Nahmanides for blasphemy. The pope sided with the Dominicans and forced the king of Aragon to punish Nahmanides who eventually fled to Palestine to save his own life. In this atmosphere of dispute and persecution, he turned to contemplative-theosophic Kabbalah. He was the first to give respectability to Kabbalah through his classic Bible commentary, where he combined rabbinical midrashic strategies with his own figurative and esoteric approach. ${ }^{21}$ This approach is unique because he equates the literal, the figurative and the esoteric approach, by arguing that God's Torah is complete. It includes everything, also mystical renderings of God's will. Nevertheless, Nahmanides sometimes hesitated as to the halakhic legitimacy of a mystical midrash. ${ }^{22}$

By the end of the 13th century, the prime Kabbalistic work, Sefer haZohar, appeared. It stands in the same mystical theological tradition as Sefer haBahir and the writings of Nahmanides where the notion of a micro-macrocosmic relation between the transcendent and immanent world exists. However, Sefer haZohar is unique due to its literary qualities. First, there is a deep affinity between the structures of the zoharic discourse and the rhetorical strategies of the old Midrash. ${ }^{23}$ It is in fact a midrash on the Torah, the Book of Ruth, and the Song of Songs. Secondly, the applied imagery ${ }^{24}$ constructs an almost $»$ mythical hypertext using scriptural models and images that are then used to reveal the inner message of the text, that is, the soul of Torah». ${ }^{25}$ Sefer haZohar uses a grid of images and symbols in the Torah verses as stepping stones to reveal the hidden world, including the transcendental insights and the intentions of God. This is why Sefer haZohar is a mystical midrash.

Scholars have tended to construct a hierarchical model that places the sensus spiritualis above the sensus litteralis when it comes to a mystical midrash like Sefer haZohar. Gershom Scholem, the founder of the 
historical study of Jewish mysticism, has explained that for the Kabbalist, the peshat obscures the true meaning of the Kabbalistic theology, and that this opposition between literal sense and Kabbalistic theology is what invites contemplation and a conservative-revolutionary readiness to contribute to the development of the rabbinic tradition. ${ }^{26}$ David Stern, an expert on Jewish hermeneutics, is in line with Scholem when he writes that »the literary forms of classical midrash were taken up by the ... kabbalistic movement in such works as the Sefer Bahir and the Zohar, where they were infused with a new mystical content and thereby transformed into a medium for esoteric teachings» (Stern: 618). Here, the midrashic activity only serves the purpose of reaching the esoteric teachings/sensus spiritualis. Thus, the peshat, the literal sense of the Torah is made inferior to that of the esoteric sense, and the midrashic premise of recognising the peshat of the Torah text is endangered.

The alleged zoharic tendency to evaluate the various layers of meaning hierarchically relates to the model of four interpretative levels in studies of the Torah. This model is known as PaRDeS, which is an acronym of $\mathrm{P}=$ peshat (the literal level); $\mathrm{R}=$ remez (hint, i.e. the symbolic level); $\mathrm{D}=$ derash (the homiletical level); and $\mathrm{S}=$ sod (secret, i.e. the mystical level). Despite tendencies to read the Torah on these four levels in Judaism throughout centuries, ${ }^{27}$ it was most likely under the influence of Christian exegetes ${ }^{28}$ that the author of Sefer haZohar systematised and applied the fourfold interpretative practise spurred by this argument:

Alas for the man who regards the Torah as a book of mere tales and everyday matters! If that be so, we, even we could compose a torah dealing with everyday affairs, and of even greater excellence. Nay, even the princes of the world possess books of greater worth which we could use as a model for composing such torah. The Torah, however, contains in all its words supernal truths and sublime mysteries (Sefer haZohar III, 152a).

It seems that it was a matter of the utmost importance to the author of Sefer haZohar to transcend the literal meaning of the Torah. The author's concern could lend the impression that the peshat was considered to be at the bottom of the hierarchy of sod, remez, derash and peshat, sod of course being at the top, ${ }^{29}$ as indicated by Scholem and Stern. However, the usual conception of Kabbalistic exegesis as 
a search for sensus spiritualis as hierarchically superior to sensus litteralis; i.e. the peshat, is challenged in an article by Elliot R. Wolfson where he presents a much more instrumental conception of peshat in Kabbalah.

It is Wolfson's contention that the

Zohar does not simply reject or denigrate the more normative literal-historical-grammatical understanding of peshat but operates with a theological conception of peshat that assumes that the Torah, the divine image, comprehends the mystical meaning in its most elemental and ideogrammatic form.... [The Zohar] reverts to the conception of peshat that emerges from Rabbinic writings where it signifies authorial intention as determined through an authoritative teaching (Wolfson's two italics, Wolfson: 158).

Peshat belongs to the semantic layer of the Torah. However, the exile, caused by human sin, had made man's interpretative abilities deficient. This human deficiency did not allow for the peshat to be ignored. Focussing on sod alone was subsequently equalled to the heretic's way of giving in to evil. ${ }^{30}$ Therefore, to further redemption from this deficient state of mind, one had to strive towards overcoming the deficiency of human interpretation, and the solution was sought for and found in the micro-macrocosmic relation between the immanent and transcendent sphere.

Based on the micro-macrocosmic relation, every detail in the Torah is considered a generative allusion to the transcendent sphere. The peshat becomes the gate to this sphere where God constantly reveals himself. Through contemplation upon the peshat, the mystic witnesses divine revelation on the sod level. After having witnessed this revelation, the mystic may return, cured from his deficiency to understand the Torah on his own, to suddenly see the completeness of the peshat. This »hyperliteralism» enables the mystic to gain an understanding of the Torah which will be available to everyone once redemption has taken place. Until redemption however, the mystics are the only privileged interpreters of the sacred text, who master the »hyperliteral» technique of producing mystical midrashim that actually bridge the gulf between meanings on the immanent and transcendent level. ${ }^{31}$

The midrashic attitude towards scripture combined with the hermeneutical use of sod to shed light on the peshat of the Torah verse has continued to influence interpretations within Jewish mysticism 
until today. However, history played its part and provoked more mechanical attitudes towards the use of the Torah; e.g. in Lurianic Kabbalah which emerged in the mid 16th century. From 1182 to 1497 Jews were to a large extent forced to choose between conversion to Christianity, death or expulsion in France, Italy, England, Germany, Belgium, Switzerland, Spain and Portugal. ${ }^{32}$ It was therefore no wonder that Jews all over the World sensed an intensified state of exile. How could God allow this? How would the Torah explain this? Isaac Luria (1534-1572), the man after whom Lurianic Kabbalah is named, settled in Safed in Galilee during the last years of his life. Safed was at that time famous for its learned rabbis, especially for Joseph Caro (1488-1575) who had combined his mystical orientation with a wish to promote a careful and detailed attention to the fulfilment of the commandments, cf. his legal code, Shulchan Arukh. I consider Caro's combination of mysticism and halakhic observance crucial for understanding Luria's rather bold explanation of the intensified exile where he blames the Jewish people as well as God. The Jewish people had failed to live up to their collective responsibility to keep the 613 commandments of the Torah. Jewish mystics who focussed, whether through ecstasy or contemplation, on their personal union with God, had to leave this self-centeredness behind, and engage in persuading Jewish individuals to commit themselves in a collective struggle to alter the present exilic state of the world. The exile would only come to an end, if every Jew kept the commandments. However, that the exile had come around in the first place, was due to a mistake made by God.

According to the Lurianic myth, in which Luria explains how God created the world, the listener becomes aware that this world as we know it is the result of a cosmogonic disaster. During God's initial attempt to create the world, God decided to create it by comprising his infinity into finite vessels made of the essence of God's stern judgment. However, the vessels broke and shattered into the universe. The shells from the broken vessels were made of divine judgment. When the material of the vessels was in direct contact with God's infinity, the vessels represented a necessary confinement. However, now that the material of judgment had been severed from God, it came to represent evil. The shells sponged on the residue from God's infinity floating around in the universe like sparks of light. The evil shells gained strength and 
encapsulated the divine sparks. Thus, the divine essence in the world was confined by evil, and this pertains until this day to all of creation. According to this myth, only Jews can help God lift the divine sparks out of the shells. Such uplifting of the sparks is called tikkun; i.e. restoration. $^{33}$

It follows from this myth, that the evil shells limit man's ability to understand the Torah, which is why the Lurianic myth replaces the inherent theological messages in the Torah and reduces the function of the Torah to offer guidance on how to perform the commandments. Nevertheless, this does not exclude that mystics still searched for answers in the Torah. Hayyim Vital (1543-1620), a close follower and secretary of Luria, argued intensively for »the inherent necessity of the peshat and its organic relation to the sod or inner meaning», as Wolfson puts it. ${ }^{34}$ Nevertheless, I am not aware of any real mystical midrashim in Lurianic Kabbalah. ${ }^{35}$

Hasidism is the most recent major trend in Jewish mysticism, emerging in the mid 18th century. Hasidism has ecstatic as well as contemplative traits. A circle of charismatic itinerant preachers and miracle workers, among whom Israel ben Eliezer Ba'al Shem Tov became the most famous, proclaimed that the Jewish population, neglected by the rabbinic representatives in the major cities of Eastern Europe, had no reason to despair in times of poverty, rationalism and massacres. Inspired by the Lurianic myth, Hasidic theology disseminated the joyous message that divine sparks were everywhere and in each individual, which is why unmediated contact with God was possible. Unmediated contact was only a matter of uplifting the divine sparks within oneself, one's fellow humans or in nature. This theological notion of God's presence in everything; i.e. pantheism, was coupled with the more complex thought of pan-en-theism; i.e. everything is within God. Pan-en-theism conveyed the idea that the only reality was the transcendent realm of God, called Ayin, which humans, however, could not recognise, because the evil shells had confined human perception. So Hasidic pantheism, which could appear as a very democratic thought, was forced to exist side by side with the elitist concept of pan-en-theism, where the zaddikim; i.e. the righteous men who functioned as religious specialists, were the only ones capable of bringing individuals to uplift the sparks that covered 
their ability to perceive God within themselves. ${ }^{36}$ Thus, the zaddikim were needed as mediators despite God's unmediated presence within each individual.

Ecstatic practises such as dancing, drinking, smoking, seclusion and recitation, etc. were introduced as ritualistic techniques for everyone to uplift the sparks. However, the zaddikim, who needed to know what the world looked like from God's perspective in order to guide the followers, returned in some cases to the now canonical works of contemplative-theosophic Kabbalah, such as the mystical midrash Sefer haZohar, to gain insights into the multiple layers of meaning in the Torah.

Sefer haZohar inspired the interpretative practises among the leaders who engaged in midrashic expositions in their homiletic sermons. ${ }^{37}$ Wolfson relates how the grandson of Ba'al Shem Tov, Moses Hayyim Ephraim of Sudlikov (1737-1800), argued that one first has to focus on the literal wording of a Torah verse. Secondly, one shall expand its meaning to include the secrets of the Torah. Finally, one »should return and come [to an understanding of] the true literal sense ( $h a-$ peshat ha-'emet)»(Wolfson's brackets and parentheses, quoted after Wolfson: 173).

The great-grandson of Ba'al Shem Tov, Nahman of Bratslav (17721810) however, produced the most innovative way of using the Torah. In his collection of homiletic sermons, known as Likkutey MoHaRaN, Nahman returns to the complex structure of classical midrash where exegetical bridges are built between the seder verse and the 'distant verse'. However, instead of introducing a scriptural verse as the 'distant verse', Nahman replaces it with halakhic instructions on how to engage in divine worship or pietistic conduct. ${ }^{38}$ One could conceive of this as a return to traditional Judaism. But it is not. Nahman's adherence to halakhically correct conduct is what legitimises his hidushim; i.e. his innovations, when it comes to the final reading of a Torah verse. On the one hand he speaks about how to adhere to the commandments; on the other hand he introduces himself as the only one in this world who has access to the transcendent sphere and thereby to God's will concerning human understanding of the Torah. Nahman himself has become the sod of the Torah verse, God's mediator on Earth, a new Moses. By showing how he as mediator sheds light on the otherwise incompre- 
hensible imagery in the seder verse, Nahman produces completely new sacred texts, inscribing them in Jewish tradition through halakhic instructions. ${ }^{39}$ What we have here is something very strange. The peshat of the Torah verse is initially ignored. However, a literal reading of the commandments is introduced in the 'distant verse', which legitimises that Nahman presents his associations, rendered as God's counsel, as the sod, that very much like in Zoharic Kabbalah sheds light on the peshat of the Torah verse. This is on the verge of being a mystical midrash. However, because Nahman does not draw upon an established mystical theology but his own, Shaul Magid suggests that Nahman's homiletic sermons are labelled associative midrashim. ${ }^{40}$

\section{Conclusion}

As described above, there are several uses of the Torah in Jewish mysticism. If one chooses a very loose definition of midrash as mere interpretation, one could say that all of Jewish mysticism represents a midrash of Jewish tradition. However, this is not desirable. In stead by distinguishing, first between a mechanical and a hermeneutical use of the Torah, it is possible to exclude the practises where the Torah has been used for purely ecstatic reasons. Secondly, by respecting the Talmudic saying that »a Torah verse should not lose its literal sense (peshat)» it is possible to establish a minimum relation between a Torah verse and its interpretation, which qualifies for the term 'midrash'. Finally, by using the three labels: traditional, mystical and associative midrash, it is possible to distinguish between an either rabbinical, mystical or individual theology, which again reveals the existing or lacking ability of the religious institutions to explain adequately the historical and personal events in Jewish lives. Based on these distinctions, I therefore define mystical midrash as the act of interpreting the details of a Torah verse with the purpose of entering a meditative or ecstatic state of union with God, in which the mystic by drawing down God's insights can explain how the Torah verse mediates the micro-macrocosmic relation between God's will and the course of history. 


\section{Notes}

1. Cf. Mishnah Yoma 8, 8-9.

2. Cf. Babylonian Talmud Shabbat 63a; Yevamot 11b; $24 a$.

3. Halivni 1991: 9.

4. Stern 1987: 617.

5. Idel 1993: 49-50.

6. What Idel has in mind is probably the rhetorical function of the theological discussions between various scholars in the Talmud who present their different views on a subject, the point being that the interpreting community has to perceive of itself as part of the discussion. Being a legitimate part of the discussion through the idea of Oral Torah each community must recognise its responsibility to draw the theological conclusion itself; thus contributing to the multidimensional theology of rabbinic Judaism.

7. Parrinder 1976: 8.

8. Parrinder 1976: 11-14. Gershom Scholem was the first to emphasise that there is no mysticism as such, there is only the mysticism of a particular religious system", cf. Scholem 1974: 6. Mysticism will always be influenced by a particular religious worldview, whenever a mystic tries to describe his/her altered state of consciousness (ASC) or feeling of union. On ASCs, cf. Wulff 1991: 61-82.

9. On via negativa, cf. Scholem 1974: 11.

10. On symbolism, cf. Scholem 1974: 27-28. On the mystic's dependency of symbols from his/her own culture, cf. Scholem 1974: 5-6.

11. For more on the informative and performative function of tension between likenesses and differences in imagery, cf. Nielsen 1989.

12. E.g. Frennesson 1999; Wolfson 1994.

13. E.g. Scholem 1971: 51-54; Schäfer 1988: 293.

14. bHagigah $14 \mathrm{~b}$. Concerning the age limit of fourty years, it may be derived from bBaba Metsia 33a combined with the fact that God orders the ministering angels to leave »this elder» be, cf. bHagigah 15b.

15. Steensgaard 1990: 73 .

16. Accounts exist of how mystics would curl up, place their heads between their knees, recite religious texts, and begin envisioning an ascent through the various halls (hekhalot in Hebrew) in the divine sphere, cf. Rabbi Hai Gaon: Otser haGeonim leMas' Hagigah 14b, »helekh teshuvot». David M. Wulff has explained how deprivation due to fasting, lack of blood transferral to the brain because of awkward body positions, and monotonous recitation of texts, alter the state of consciousness, cf. Wulff 1991: 41-110.

17. On the mystical elements in Maimonides' philosophy, cf. Pines 1986: 10.

18. Cf. Maimonides 1963: Chapter 51.

19. Scholem's dissertation was an annotated translation of Sefer haBahir, cf. Scholem (1923) 1970.

20. The two concepts 'sensus litteralis' and 'sensus spiritualis' derive from Thomas Aquinas, cf. Wolfson 1993: 158n21.

21. Twersky 1983: 4-7.

22. Berger 1983: 112n19.

23. Cf. Idel 1993: 54.

24. For a detailed survey of the applied imagery in Sefer haZohar, cf. Tishby 1989: Vol. I, 290-302.

25. Magid 2002: 17. Scholem formulated the zoharic distinction between the Torah and the soul of Torah too. The latter corresponds to »the most deeply hidden 
of all, which remains insensible and unintelligible to all but God», Scholem 1974: 208.

26. Scholem 1978: 13; 33; Scholem 1974: 14.

27. Cf. Wolfson 1993: 156.

28. Cf. Scholem 1974: 210, and possible contact to Franciscan Itinerant monks through a common interest in the concept of poverty, cf. Scholem 1974: 234.

29. Cf. Scholem 1974: 210-211.

30. Cf. Wolfson 1993: 166.

31. Cf. Wolfson 1993: 167; 172.

32. Cf. Cohn-Sherbok 1994: 91-92.

33. Cf. Scholem 1974: 244-286.

34. Cf. Wolfson 1993: 187.

35. Sabbatianism, a movement from the mid 17 th century, did not produce any mystical midrashim either. It adopted the Lurianic theology and combined it with an intense messianism. When the messiah candidate of this movement, Sabbatai Tsvi (1626-1676) was forced to convert to Islam, he himself, his prophet and his followers interpreted this conversion into the Lurianic theology as a necessary confrontation of evil within the domain of the ultimate evil to uplift the most confined sparks. Traditional Judaism, including many mystical Jews could of course not accept conversion to a rival religion as a legitimate part of Jewish theology, and so they stamped the Sabbatian movement as heretical. This pertains to the Frankist movement as well, where Jacob Frank (1726-1791) advocated for conversion to Catholic Christianity.

36. For the elitist traits of Hasidism, cf. Rapoport-Albert 1997: 76-140.

37. Idel 1993: 55-56.

38. Magid 2002: 38-39.

39. Schleicher 2002: 31-42.

40. Cf. the title of Magid 2002.

\section{Bibliography}

Berger, David 1983: "Miracles and the Natural Order in Nahmanides», ed. Twersky: Rabbi Moses Nahmanides (RaMBaN): Explorations in His Religious and Literary Virtuosity, Harvard University Press, Cambridge MA.

Cohn-Sherbok, Dan 1994: Atlas of Jewish History, Routledge, London.

Frennesson, Björn, 1999: "In a Common Rejoicing» - Liturgical Communion with Angels in Qumran, Acta Universitatis Upsaliensis, Uppsala 1999.

Halivni, David Weiss, 1991: Peshat and Derash - Plain and Applied Meaning in Rabbinic Exegesis, Oxford University Press, Oxford.

Idel, Moshe, 1993: »Midrashic versus Other Forms of Jewish Hermeneutics: Some Comparative Reflections», ed. Fishbane: The Midrashic Imagination - Jewish Exegesis, Thought and History, SUNY Press, Albany.

Magid, Shaul, 2002: »Associative Midrash»; in ed. Magid: God's Voice from the Void - Old and New Studies in Bratslav Hasidism, SUNY Press, Albany.

Maimonides, Moses, 1963: The Guide of the Perplexed, trans. Pines, University of Chicago Press, Chicago.

Nielsen, Kirsten, 1989: There is Hope for a Tree - The Tree as Metaphor in Isaiah, JSOT Supplement Series 65, Sheffield Academic Press, Sheffield.

Parrinder, Geoffrey, 1976: Mysticism in the World's Religions, Sheldon Press, London. 
Pines, Shlomo, 1986: $»$ The Philosophical Purport of Maimonides' Halachic Works and the Purport of The Guide of the Perplexed»; ed. Pines \& Yovel: Maimonides and Philosophy - Papers Presented at the Sixth Jerusalem Philosophical Encounter, May 1985, Martinus Nijhoff, Dordrecht.

Rapoport-Albert, Ada, 1997: Hasidism Reappraised, Littman Library, London.

Schäfer, Peter, 1988: Hekhalot-Studien, Mohr, Tübingen.

Schleicher, Marianne, 2002: A Theology of Redemption - An Analysis of the Thirteen Tales in Rabbi Nahman of Bratslav's Sippurey Ma'asiyot, Ph.D.-dissertation, the University of Aarhus, Århus.

Scholem, Gerhard, (1923) 1970: Das Buch Bahir, Wissenschaftliche Buchgesellschaft, Darmstadt.

Scholem, Gershom (1941) 1974: Major Trends in Jewish Mysticism, Schocken Books, New York.

Scholem, Gershom, (1977) 1978: On the Kabbalah and Its Symbolism 1977, Schocken Books, New York.

Steensgaard, Peter, 1990: »Merkavah-mystikken: Den ældste jødiske mystik», ed. Bilde \& Geertz: Mystik - den indre vej? En religionshistorisk udfordring, Aarhus Universitetsforlag, Århus.

Stern, David, 1987: »Midrash», eds. Cohen \& Mendes-Flohr: Contemporary Jewish Religious Thought, Charles Scribner's Sons, New York.

Tishby, Isaiah, 1989: The Wisdom of the Zohar - An Anthology of Texts, Littman Library, Oxford.

Twersky, Isadore (ed.), 1983: Rabbi Moses Nahmanides (RaMBaN): Explorations in His Religious and Literary Virtuosity, Harvard University Press, Cambridge MA.

Wolfson, Elliot R., 1993: "Beautiful Maiden Without Eyes: Peshat and Sod in Zoharic Hermeneutics», ed. Fishbane: The Midrashic Imagination - Jewish Exegesis, Thought and History, SUNY Press, Albany.

Wolfson, Elliot R., 1994: »Mysticism and the Poetic-Liturgical Compositions from Qumran. A Response to Bilhah Nitzan», Jewish Quarterly Review 85, 185-202.

Wulff, David M., 1991: Psychology of Religion - Classic and Contemporary Views, John Wiley \& Sons, New York. 